\title{
AMPHIBIAN CONSERVATION IN THE CAATINGA BIOME AND SEMIARID REGION OF BRAZIL
}

\author{
Milena Camardelli ${ }^{1,3}$ and Marcelo F. Napoli ${ }^{2}$ \\ ${ }^{1}$ Programa de Pós-Graduação em Ecologia e Biomonitoramento, Instituto de Biologia, Universidade Federal da Bahia, \\ Rua Barão de Jeremoabo, Campus Universitário de Ondina, 40170-115 Salvador, Bahia, Brazil \\ ${ }^{2}$ Museu de Zoologia, Departamento de Zoologia, Instituto de Biologia, Universidade Federal da Bahia, Rua Barão de \\ Jeremoabo, Campus Universitário de Ondina, 40170-115 Salvador, Bahia, Brazil
}

Abstract: The Brazilian Ministry of the Environment (Ministério Do Meio Ambiente, MMA) proposed defining priority areas for Brazilian biodiversity conservation in 2007, but to date, no definitions of priority areas for amphibian conservation have been developed for the Caatinga biome or the semiarid region of Brazil. In this study, we searched for "hot spots" of amphibians in these two regions and assessed whether the priority areas established by the MMA coincided with those suitable for amphibian conservation. We determined amphibian hot spots by means of three estimates: areas of endemism, areas of high species richness, and areas with species that are threatened, rare, or have very limited distributions. We then assessed the degree of coincidence between amphibian hot spots and the priority areas of the MMA based on the current conservation units. We analyzed areas of endemism with the use of a parsimony analysis of endemicity (PAE) on quadrats. The Caatinga biome and semiarid region showed four and six areas of endemism, respectively, mainly associated with mountainous areas that are covered by isolated forests and positively correlated with species richness. All areas of endemism coincided with one or more priority areas defined by the MMA. We identify 15 priority areas for amphibian conservation in the Caatinga biome and semiarid region, including the creation of new full-protection conservation units.

Resumo: A definição de áreas prioritárias para a conservação da biodiversidade brasileira foi proposta pelo Ministério do Meio Ambiente (MMA) em 2007, mas até o presente momento não há estudo metódico que defina áreas prioritárias para a conservação de anfíbios no bioma Caatinga ou no Semiárido brasileiro. Neste estudo, buscamos por "hot spots" de anfíbios nestes dois polígonos e verificamos se as áreas prioritárias do MMA coincidem com áreas adequadas para a conservação dos anfíbios. Determinamos os hot spots de anfíbios por meio de três estimadores: áreas de endemismo, áreas de alta riqueza de espécies e áreas com espécies ameaçadas, raras e/ou com padrões de distribuição restrita. Em seguida, acessamos o grau de coincidência entre hot spots de anfíbios e áreas prioritárias do MMA, igualmente considerando as unidades de conservação correntemente instaladas. A detecção de áreas de endemismo foi realizada pela Análise de Parcimônia de Endemicidade (PAE), usando quadrados. O bioma Caatinga e o Semiárido apresentaram, respectivamente, quatro e seis áreas de endemismo, principalmente associadas a áreas montanhosas cobertas por florestas isoladas, e estiveram positivamente correlacionadas à riqueza de espécies. Todas as áreas de endemismo coincidiram com uma ou mais áreas prioritárias definidas pelo MMA. Nós identificamos 15 áreas prioritárias para conservação de anfíbios no bioma Caatinga e Semiárido, além da criação de novas unidades de conservação de proteção integral no Brasil.

Key words: Amphibians; Complementarity analysis; Parsimony analysis of endemicity; Priority areas; Species richness; Threatened species

The Determination of priority areas for the conservation of biological diversity has received much attention in recent years (Tabarelli and Silva, 2004). The Convention on Biological Diversity (CBD), signed during the UN Conference on Environment and Development (UNCED) in 1992, aimed to generate guidelines to reconcile the economic development of nations with the conservation and sustainable use of biological resources (Tabarelli and Silva,

\footnotetext{
${ }^{3}$ Correspondence: e-mail, milenacamardelli@yahoo. com.br
}

2004). To meet these obligations, the Brazilian Ministry of the Environment (Ministerio Do Meio Ambiente, MMA) developed its first "assessment and identification of priority areas and actions for the conservation of biomes" between 1998 and 2000, and updated it in 2007. The definition of the priority areas was based on the available information about biodiversity and human pressures, in addition to the experience of researchers, and the degrees of priority were defined with the use of criteria for biological richness, areas of endemism, and the distributions of endangered species. Furthermore, 
the importance of these areas to traditional communities and indigenous peoples and their vulnerability were also taken into account (MMA, 2007).

An important element of subjectivity in the listing of priority areas proposed by the MMA (2007) is that a sizeable part of the information used in the delineation of these areas came from personal and single observations or from nonmethodical or poorly designed studies (M.F. Napoli, member of the Caatinga Thematic Group of MMA, personal communication, 2007). A second important aspect is that the level of knowledge and interest in each Brazilian biome and in the various biological groups that make up the Brazilian biodiversity is uneven, which led to an arbitrary and subjective selection of priority areas for conservation.

Because of this history, it is necessary to determine the degree of congruence between the priority areas for Brazilian biodiversity conservation as defined by the MMA (2007) and important areas for conservation of the various taxonomic groups defined by biological studies conducted methodically for this purpose, such as those aimed at identifying areas of endemism. Areas of endemism include unique biota that result from various types of isolation and that, once identified, can illuminate the natural processes that led to their origins (Silva, 2008).

Another important question to be answered is whether the Caatinga biome and the Brazilian semiarid region are identical with respect to biological diversity, as they largely overlap geographically. Nevertheless, a biome, as conceived by the Instituto Brasileiro de Geografia e Estatística (IBGE, 2004a), is a set of vegetation types identifiable on a regional scale, including its allied fauna and flora, with similar geoclimatic conditions and a shared history of changes that resulted in biological diversity. On the other hand, the semiarid region is defined based on Brazilian drylands with similar climatic characteristics (Ministério da Integração Nacional [MIN], 2005): average annual rainfall, aridity index (the relationship between rainfall and potential evapotranspiration), and drought risk. Therefore, the Caatinga biome and the Brazilian semiarid region are conceptually different, and hence have different areas and boundaries.
With respect to amphibians, there have been no methodical studies that define priority areas for their conservation in the Caatinga biome or in the semiarid region of Brazil, which points to the urgent need to test whether the priority areas listed by the MMA (2007) for biomes in the Brazilian territory include the hot spots for amphibians in these regions. If the congruence is not complete, then it will be necessary to redefine the priority areas for conservation or to propose new areas to ensure the conservation of hot spots for amphibians in these areas.

This study aims (1) to identify hot spots of amphibians in the Caatinga biome and semiarid region of Brazil by combining areas with high levels of endemism and species richness with areas that contain species that are threatened, rare, or have very limited distributions; and (2) to determine whether the priority areas defined by the MMA (2007) coincide with areas important to amphibian conservation.

\section{Materials and Methods}

\section{Study Area}

The Caatinga is the only biome unique to Brazil and has been recognized as a biogeographic province of the Chacoan subregion (Morrone, 2006). This biome is distributed throughout the northeast region of Brazil (except for the State of Maranhão) and the northern part of the State of Minas Gerais (Fig. 1), covers an area of $852,261 \mathrm{~km}^{2}$, and represents $11 \%$ of the Brazilian territory (MMA, 2007). The Caatinga biome is characterized by semiarid to arid climates (Santos and Tabarelli, 2003) with long dry seasons, irregular rainfall (concentrated in the summer), average annual precipitation of 400 to $600 \mathrm{~mm}$ (Ab’Sáber, 1977), high annual temperatures $\left(\mathrm{ca} .27^{\circ} \mathrm{C}\right)$, and a large temperature range (MMA, 2007).

Although the most common landscape in the Caatinga biome is the steppe savanna, which is composed of thorny and deciduous plants and rivers that are largely intermittent and seasonal (MMA, 2007), the biome is not physically homogeneous and can be divided into smaller ecoregions (Velloso et al., 2002). In this landscape, mountain massifs reach elevations of over $2000 \mathrm{~m}$ above sea level 


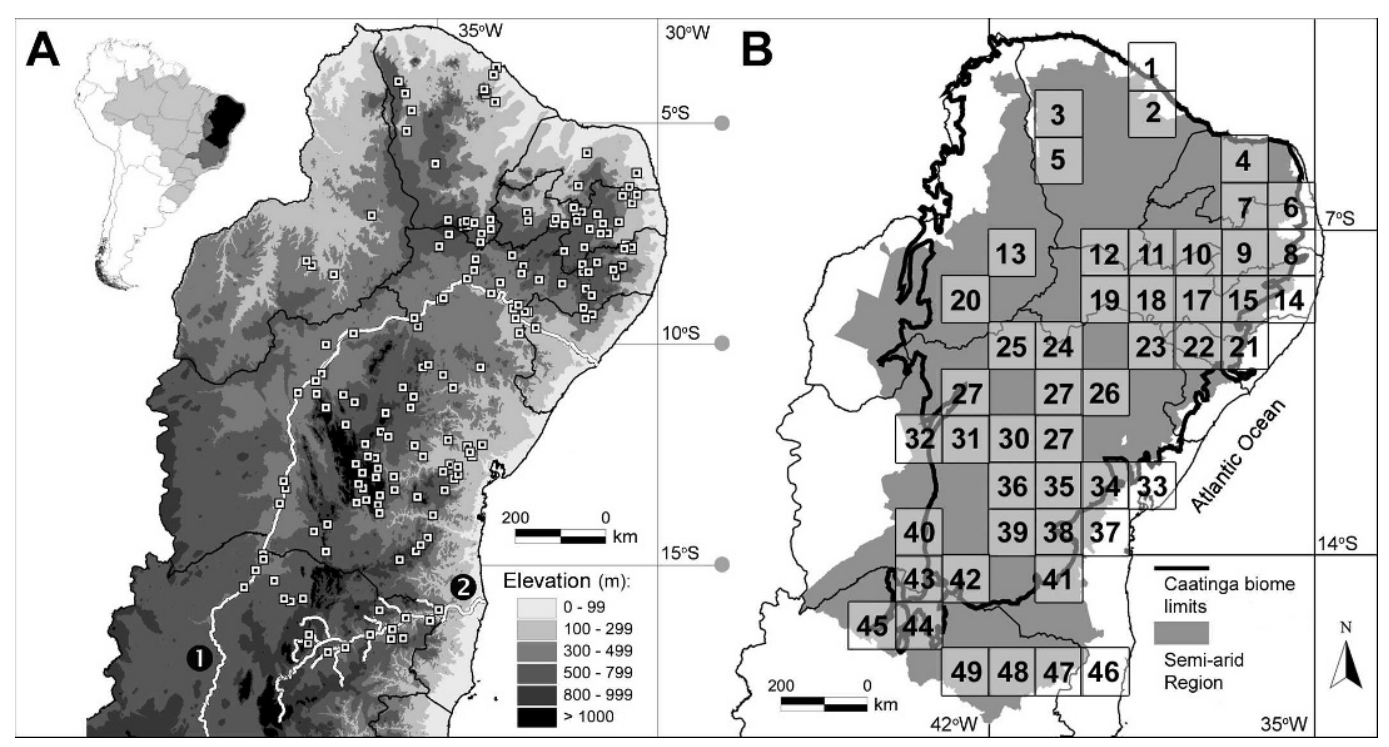

FIG. 1.-(A) Topographic map with the anuran sampling locations included in the analysis: 1, São Francisco River; 2, Jequitinhonha River. (B) Distribution map of the 48 quadrats (operational geographic units) considered for analysis within the limits of the Caatinga biome and semiarid region of Brazil.

(masl), creating zones of geomorphologic and climatic uniqueness (Ab’Sáber, 1977) that harbor rocky mountain fields called "Campos Rupestres" (for a description of Campo Rupestre, see Rizzini, 1979), riparian forests, and seasonal deciduous and semideciduous forests. Of high biological importance, these mountainous environments and rough terrains show high degrees of endemism (Giaretta and Aguiar, 1998; Haddad and Abe, 1999; Naniwadekar and Vasudevan, 2007) and can present barriers to the dispersal of various phylogenetic groups, in addition to acting as centers of speciation and refuge (Carnaval, 2002; Carnaval and Moritz, 2008).

The semiarid region comprises almost the entire area of the Caatinga biome as well as the transitional areas between this biome and the Cerrado and Atlantic Forest biomes (Fig. 1), which makes it slightly more heterogeneous than the Caatinga biome in terms of physical features, although it is similar to the Caatinga biome in terms of topography and climate. The semiarid region represents $11.4 \%$ of the Brazilian territory, covers an area of $969,589 \mathrm{~km}^{2}$, and has recently had its area and number of municipalities increased by MIN (2005) because of changes in its boundaries.

\section{Database Preparation}

For this analysis, we considered only species with clearly defined descriptions and diagnoses (e.g., species suspected of constituting species complexes were discarded). We considered only anuran amphibians, because the fossorial habits of gymnophionans (Duellman and Trueb, 1986) invariably leads to the undersampling, and because urodeles do not occur in the study area (Frost, 2009).

The locations considered in this study were those included in the coverage areas of the Caatinga biome or the semiarid region (states of the northeast region of Brazil, except for Maranhão, and part of the State of Minas Gerais). First, we searched the literature (articles, books, notes on natural history and geographical distribution, and dissertations and theses) for amphibian species that occur in the studied areas. We critically reviewed information about species and their locations before entered them into the database. Next, we investigated in loco the following Brazilian herpetological collections: the Museu Nacional (Rio de Janeiro State), the Museu de Zoologia da Universidade Estadual de Feira de Santana (Bahia State), the Museu de Zoologia da Universidade Federal da Bahia (Bahia State), the Museu de Zoologia da the 
Universidade de São Paulo (São Paulo State), and the Laboratório e Coleção de Herpetologia da Universidade Federal da Paraíba (Paraíba State). In the absence of accurate information on the geographic coordinates for the collection site of any particular specimen, we used the geographic coordinates of the respective municipality. We digitized and mapped the locations of all samples, as described below, to determine whether they were contained within the boundaries of at least one of the regions under study. We excluded from the analysis samples that were outside both polygons.

\section{Mapping and Analysis of Georeferenced Data}

We converted the geographical coordinates of each location into decimal format, digitized them in ARCVIEW software version 3.2a (Environmental System Research Institute [ESRI], 2000), and projected them over the polygons of the Caatinga biome and the semiarid region. We obtained the following area boundaries (polygons): the Federal states of Brazil, from the database Digital Chart of the World (ESRI, 1997); the Brazilian biomes, from the digital vector map "Biomas do Brasil," scale 1:5,000,000 (IBGE, 2004b); the semiarid region, from the digital vector map "Redelimitação do Semi-árido Nordestino," scale 1:298.250 (Secretaria de Políticas de Desenvolvimento Regional [SPDR], 2005); the bioclimatic suitability of the Brazilian Northeast, from the digital map "Aptidão Bioclimática no Bioma Caatinga," scale 1:300,000 (Companhia Hidroelétrica do São Francisco [CHESF], 2001); the climatic suitability of the State of Minas Gerais from digital vector maps of "Agroclimatic zoning of the State of Minas Gerais," scale 1:3,000,000 (Geoprocessamento em Minas Gerais [GEOMINAS], 2009); and the priority areas for biodiversity conservation, from the digital vector map "Revisão das áreas prioritárias para conservação da biodiversidade (importância biológica)" (MMA, 2007). We obtained the topographic base of South America from the global digital elevation model (DEM) GTOPO30 (US Geological Survey [USGS], 1996).

\section{Determination of Areas of Endemism}

Areas were considered endemic regions if they had congruent distribution limits of two or more taxa, in accordance with Platnick (1991). In the search for areas of amphibian endemism, we included all anuran species occurring in the studied area, even if they also occurred in other biomes, because we sought to maximize the search for important areas of amphibian diversity (areas of endemism, high species richness, or distribution of relictual species) to contribute to the effective maintenance of this diversity in the regions studied.

We identified areas of endemism with the use of the method of parsimony analysis of endemicity (PAE; Rosen, 1988), with modifications by Morrone (1994). Parsimony analysis of endemicity involves five basic steps: (1) the selection of operational geographic units (OGUs), (2) construction of a matrix of species vs. OGUs, (3) parsimony analysis of the data matrix, (4) the identification of the OGUs or groups of OGUs with at least two endemic species, and (5) mapping the locations where the endemic species were found within each OGU or group of OGUs to delineate the boundaries of each area of endemism. We defined each OGU as a quadrat (grid) of $1^{\circ}$ of latitude by $1^{\circ}$ of longitude (Fig. 1) as proposed by Morrone and Escalante (2002). We removed from the analysis species present in all quadrats because they did not contribute to discrimination among areas. To avoid the use of subsampled quadrats, we used only those quadrats with one or more geographical samples were represented by eight or more species. This criterion represented the lowest number of species obtained in both published and unpublished inventories, with collection efforts considered adequate (minimum 60 person-hr per locality in the rainy season in the Caatinga biome or semiarid region).

We produced two binary data matrices (absence $=0$, presence $=1$ ): a matrix of 73 anuran species (columns, analogous to traits in a cladistic analysis) vs. 35 quadrats (rows, analogous to taxa in a cladistic analysis) for the Caatinga biome and a matrix of 107 anuran species vs. 48 quadrats for the semiarid region. A hypothetical quadrat containing " 0 " in all columns was added as an outgroup in both matrices. These matrices were constructed and edited in MESQUITE software version 2.71 (Maddison and Maddison, 2009). 
A most-parsimonious geographical cladogram was sought by heuristic search with the use of the Willi Hennig Society edition of TNT software version 1.1 (Goloboff et al., 2008), with an estimated 100 replicas for 10,000 randomizations and saving 10 trees per replication. A strict consensus tree was estimated from all of the resulting trees, conserving the most robust groupings of quadrats because the influence of widely distributed species was minimized (Morrone, 1994). In the strict consensus cladogram, we considered quadrats or sets of quadrats supported by two or more endemic species (synapomorphies in the cladogram) to be areas of endemism (Morrone, 1994). Next, we mapped the areas of endemism of anurans as described above with the use of ARCVIEW software version $3.2 \mathrm{a}$, having as limits the quadrats in which the endemic species were distributed. We then superimposed the areas of endemism over the priority areas determined by the MMA (2007) to assess the degree of coincidence between them. We tested the null hypothesis of no association between species richness and number of endemic species in areas of endemism with the use of Pearson's correlation analysis $(r)$ on log-transformed data (Sokal and Rohlf, 1981). We tested the assumptions of normality and homoscedasticity with the Shapiro-Wilks test and the Levene's test, respectively, and found that they were not violated. We set the $\alpha$ level of significance to $P \leq 0.05$. We carried out the computations with the software PAST (Paleontological Analysis), version 2.12. Species used in the analyses are listed in Appendix 1 and quadrats are mapped in Fig. 1.

\section{Determination of Priority Areas}

We determined priority areas for amphibian conservation in the Caatinga biome and semiarid region by searching for areas that combined endemic species, high to very high anuran species richness, threatened species, and species with restricted geographical distributions. We ranked areas from medium to extremely high importance based on four cumulative, equally weighted parameters: (1) presence of endemic amphibians, (2) high or very high species richness, (3) presence of endangered species (sensu International
Union for Conservation of Nature [IUCN], 2001), and (4) presence of species known only from a single locality. By summing parameters we ranked areas in the following order of importance (parameter counts in parentheses): high (1), very high (2-3), and extremely high (4). To break ties within each category of importance we conducted a Complementarity Analysis (Humphries et al., 1991) considering only the previously identified priority areas. This method classifies areas in priority order, considering the most possible biological diversity and assigning greater importance to those of higher species richness. The complementarity principle is based on the identification of a first priority area, which is the area with the highest number of species. The remaining areas are ordered according to their contribution of additional species not found in the areas of higher priority. The residual complement was used to set the first priority area, and was computed as the difference between the total number of species entered in the analysis and the number of species present in an area, so that the biological diversity of an area is inversely proportional to its residual complement. The cumulative percentage, determined by the sum of the percentages of additional species to each priority area, was used to set priorities between areas (Mondragón and Morrone, 2004).

\section{Results}

For the semiarid region, we obtained 255 equally parsimonious trees of 383 steps. We obtained six areas of endemism (Fig. 2; Table 1), with quadrats indicated in parentheses: Maranguape (Q1), Jibóia-Timbó (Q34, Q37), Chapada Diamantina (Q36, Q39), Lower Jequitinhonha (Q46), Middle Jequitinhonha (Q47), and Upper Jequitinhonha (Q49). Eleven quadrats (23\%) had high (21-30 species) to very high (31-40 species) species richness (Fig. 3A), from which five quadrats (10\%) were also considered to be areas of endemism (high richness Q1, Q39; very high richness Q34, Q36-37).

For the Caatinga biome, we obtained a single most-parsimonious tree of 249 steps (Fig. 4). Four areas of endemism resulted from this analysis (Fig. 4; Table 1): Maranguape 


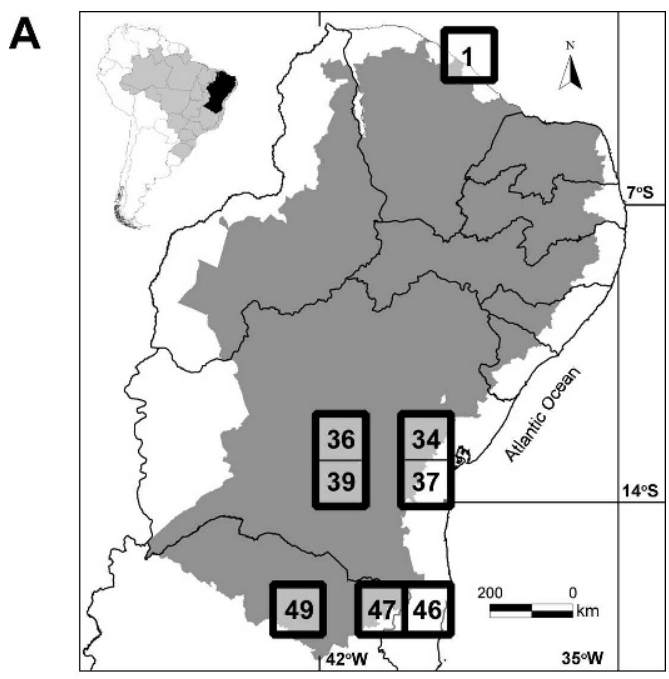

B

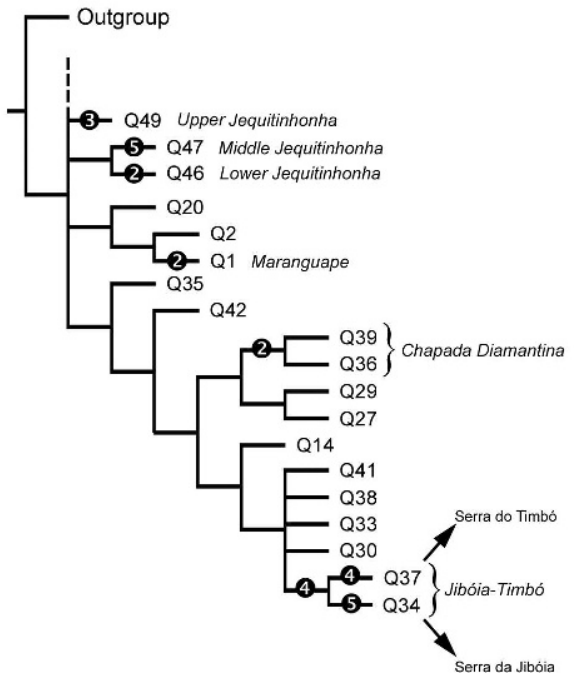

FIG. 2.-(A) Distribution map of the operational geographic units (quadrats) identified as areas of endemism for amphibians in the semiarid region (shaded area). The darkened lines delimit the areas of endemism. (B) Informative portion of the strict consensus cladogram obtained from the parsimony analysis of endemicity method with the use of $1^{\circ} \times 1^{\circ}$ latitude vs. longitude grids for amphibians of the semiarid region. Internal numbers indicate the total number of endemic species supporting areas of endemism (see Table 1 for species list).

(Q1), Chapada Diamantina (Q36, Q39), Northern Minas Gerais (Q43), and Caruaru (Q14). Six quadrats $(17 \%)$ had high to very high species richness (Fig. 3B), of which four (11\%) were also considered to be areas of endemism (high richness Q1, Q39; very high richness Q14, Q36).
In the Caatinga biome and semiarid region, the number of endemic species and species richness were positively correlated $(r=0.86$, $n=8, P<0.006$ ), with $60 \%$ of the areas of endemism for amphibians having very high (31-40 species: Q14, Q34, Q36-37; 40\%) or high species richness (21-30 species: Q1, Q39, $20 \%)$, and $40 \%$ having medium species richness (11-20 species: Q43, Q46-47, Q49).

All areas of endemism for amphibians in the studied areas were located within one or more of the priority areas for biodiversity conservation defined by the MMA (2007). However, the degree of protection offered is not homogeneous (Fig. 5; Table 2). Out of eight areas of endemism, one (12\%) has no conservation unit of integral protection (CUIP; see Sistema Nacional de Unidades de Conservação da Natureza [SNUC], 2000 for definition of the Brazilian categories of conservation units), four have one CUIP (50\%), two have two CUIPs (25\%), and one (12\%) has four CUIPs (Fig. 5).

The areas of endemism (AE) that presented the highest number of CUIPs and planned actions for the creation of protected areas (MMA, 2007; Fig. 5) were (in descending order) Northern Minas Gerais, Chapada Diamantina, Middle Jequitinhonha, Maranguape, and Lower Jequitinhonha. The following areas of endemism allocate threatened $(\mathrm{T})$, near-threatened (NT), or not evaluated (NE) anuran species (sensu IUCN, 2001) restricted to a specific locality $(\mathrm{R})$ or endemic $(\mathrm{E})$ to the Caatinga biome (CAA) or semiarid region (SAR): Lower Jequitinhonha-Aplastodiscus cavicola (NT) and Xenohyla eugenioi (E/CAA, E/SAR); Maranguape-Adelophryne maranguapensis (T, E/CAA, E/SAR); Middle JequitinhonhaAplastodiscus weygoldti (NT), and Pseudis fusca (E/SAR); and Chapada DiamantinaBokermannohyla juiju (R, E/CAA, E/SAR), Bokermannohyla itapoty (E/CAA, E/SAR), Rupirana cardosoi (NT, E/CAA, E/SAR), and Strabomantis aramunha (E/CAA, E/SAR). The Northern Minas Gerais AE did not contain anuran species with very limited distributions that were endemic to a biome or under some degree of threat.

For the Caruaru and Upper Jequitinhonha areas of endemism, there are no current proposals for creating conservation units 
TABLE 1.-Anuran species that support areas of endemism of amphibians in the semiarid region (Fig. 2) and Caatinga biome (Fig. 4). OGU = operational geographic unit.

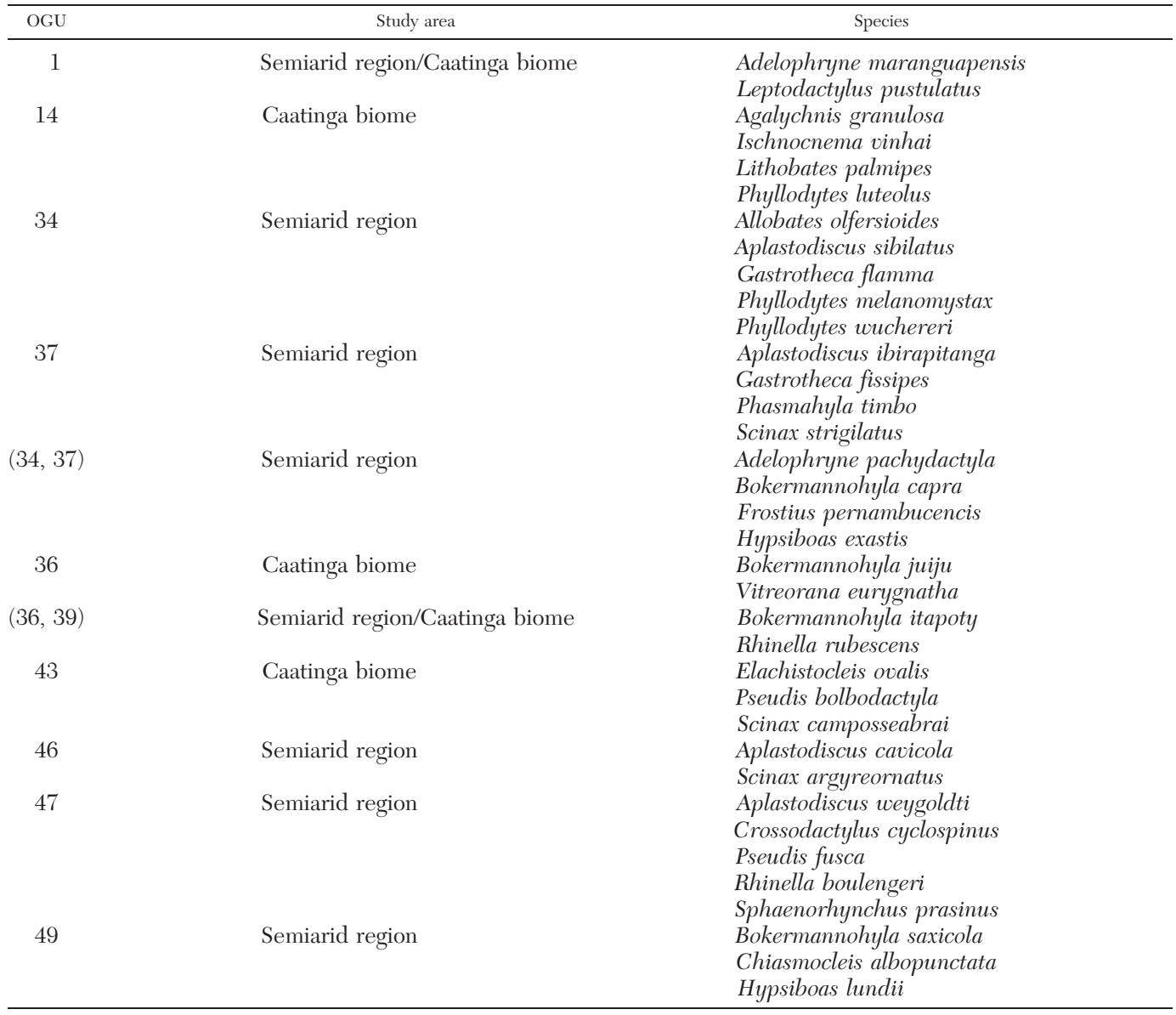

(MMA, 2007), and each one contains only a single CUIP. Moreover, they have no anuran species that have very limited distributions, are endemic to a biome, or are under some degree of threat. The Jibóia-Timbó AE does not have any existing CUIPs and only has a proposal for the creation of a conservation unit of undefined category of protection in the Serra da Jibóia (MMA, 2007). The JibóiaTimbó AE houses a threatened species (subcategory vulnerable, IUCN, 2001), Allobates olfersioides (Verdade, 2008), and is the type locality of Gastrotheca flamma, a tree frog restricted to the Serra da Jibóia that is endemic to the semiarid region and has not yet been assessed by the IUCN (2001). The nearby Serra do Timbó, not indicated for the creation of any conservation unit by MMA (2007), is the type locality of Bokermannohyla capra, which has not been assessed by the IUCN (2001), and Phasmahyla timbo, which has been evaluated as data deficient. Phasmahyla timbo is endemic to the semiarid region and limited to a forest remnant regionally known as Mata de Santa Rita in the Serra do Timbó (Cruz et al., 2008).

All areas of high or very high species richness that were not identified as areas of endemism for anurans in either the Caatinga biome or semiarid region (Q12, Q30, Q38, and Q41) overlap, at least in part, with current protected areas. For areas located within quadrats Q12, Q38, and Q41, the MMA (2007) set the creation of conservation units 


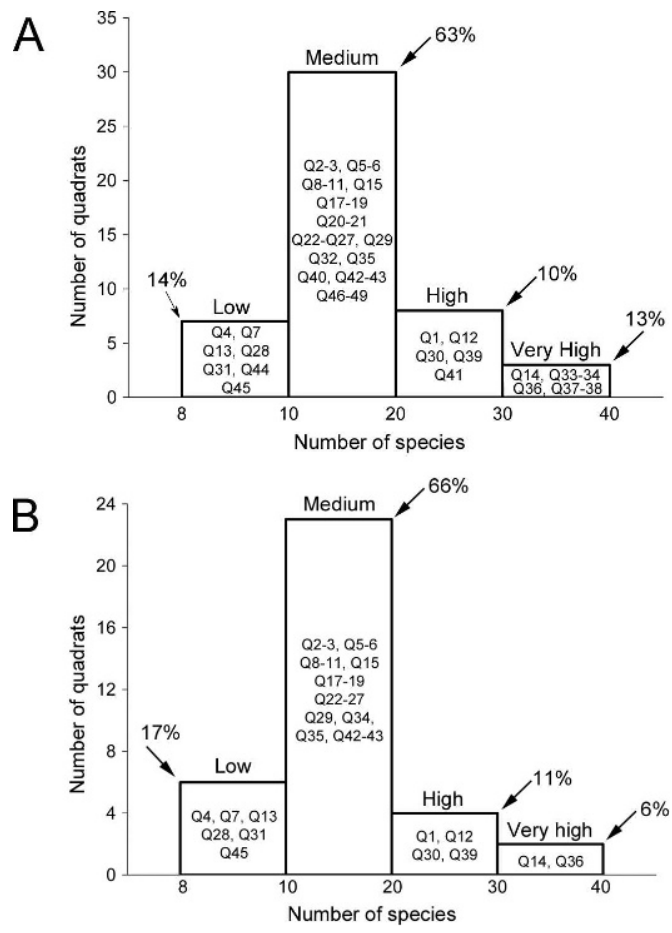

FIG. 3.-Frequency histograms of anuran species richness in the quadrats (operational geographic units): (A) semiarid region and (B) Caatinga biome of Brazil. Classes along the horizontal axis were arbitrarily categorized as follows: low species richness, 8-10 species; medium, 11-20; high, 21-30; very high, 31-40. See Fig. 1 for the geographic distribution map of related quadrats $(\mathrm{Q})$.

of integral protection as a priority action. The latter two quadrats contain three anuran species categorized as "data deficient" by the IUCN (2001) and which occur in transitional areas between the Atlantic Forest and the Caatinga biomes: Q41, Frostius erythrophthalmus (Angulo, 2008); Q38, Sphaenorhynchus bromelicola and Dendropsophus novaisi, both endemic to the semiarid region, and the former restricted to the Municipality of Maracás, State of Bahia (Peixoto and Pimenta, 2004; Silvano and Peixoto, 2004a). Seven quadrats not identified here as areas of endemism for amphibians and with low to medium species richness contained some anuran species categorized by the IUCN (2001) as "threatened" (subcategory vulnerable) or "data deficient": vulnerable-Q2, Adelophryne baturitensis, restricted to the Serra de Baturité, State of Ceará (Silvano and
A
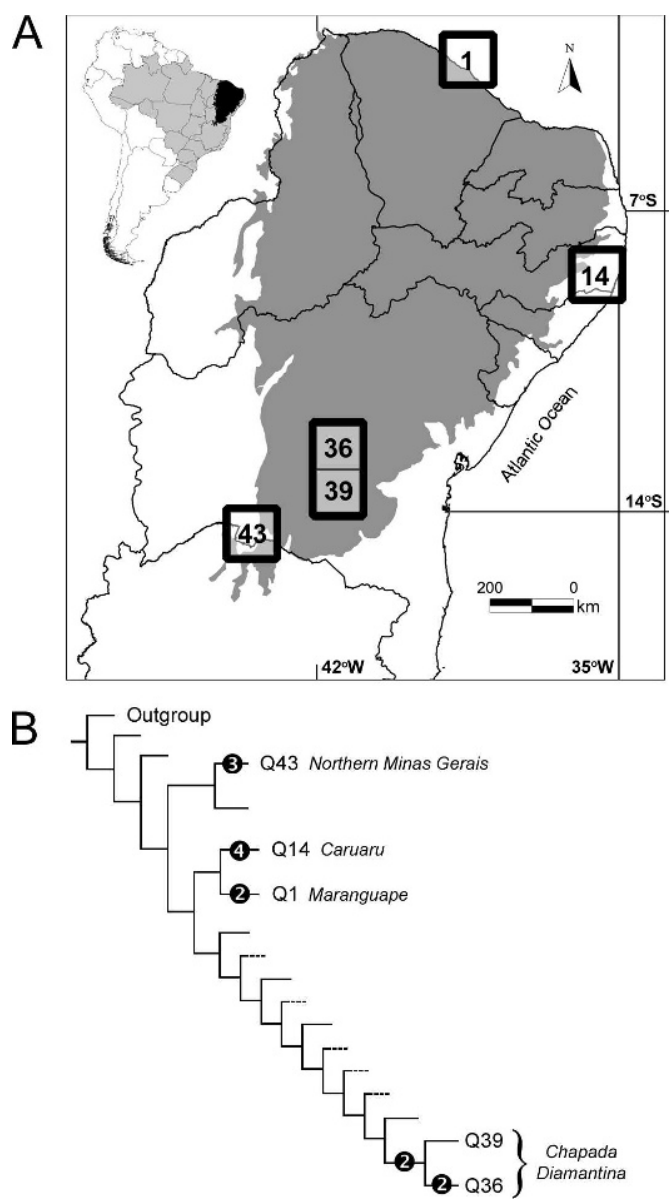

FIG. 4.-(A) Distribution map of the quadrats (operational geographic units) identified as areas of endemism for amphibians in the Caatinga biome (shaded area) of Brazil. (B) Informative portion of the strict consensus cladogram obtained from the parsimony analysis of endemicity using $1^{\circ} \times 1^{\circ}$ latitude vs. longitude grids for amphibians of the Caatinga biome. Internal numbers indicate the total number of endemic species supporting areas of endemism (see Table 1 for species list).

Borges-Nojosa, 2004); data deficient-Q6, Q8-9, and Q24, Ceratophrys joazeirensis, endemic to the Caatinga biome (Skuk and Juncá, 2004); Q21, Dendropsophus dutrai, in transition$\mathrm{al}$ areas between the coastal Atlantic Forest and the Caatinga in the states of Sergipe and Alagoas (Silvano and Peixoto, 2004b); Q48, Dendropsophus novaisi, restricted to the semiarid region within transitional areas between the coastal Atlantic Forest and the Caatinga in the municipalities of Maracás (Bahia State) and Pedra Azul (Minas Gerais State; Peixoto and Pimenta, 2004). 


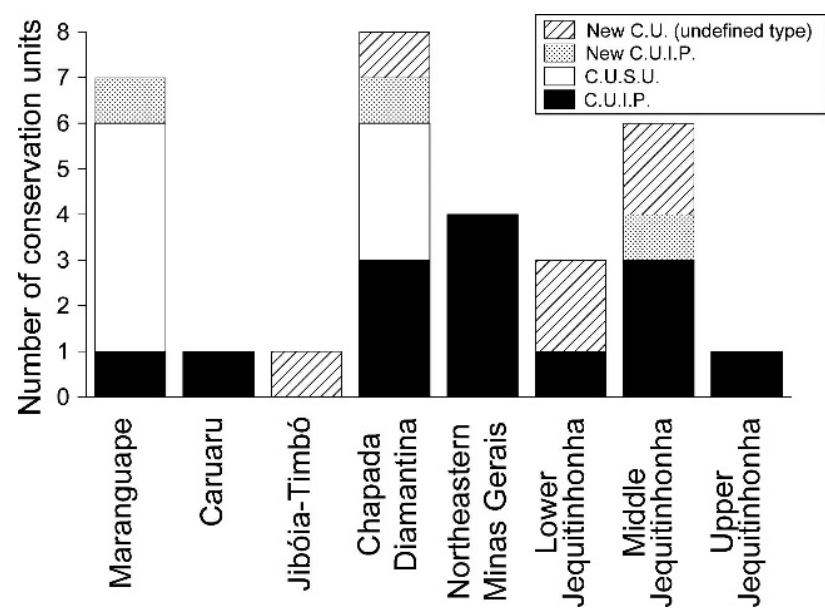

FIG. 5.-Distribution of conservation units proposed by the Brazilian Ministry of the Environment (MMA, 2007) for the semiarid region and Caatinga biome that have already been installed. CU, conservation unit; CUIP, conservation unit of integral protection; CUSU, conservation unit of sustainable use.

Out of the six species mentioned above, five (C. joazeirensis, D. dutrai, D. novaisi, $F$. erythrophthalmus, and S. bromelicola) occur in quadrats with existing CUIPs, and one (A. baturitensis) occurs in areas without CUIP, but within areas in which the MMA (2007) has made the creation of conservation units (a CUIP and an undefined conservation unit) a priority.

The combination of areas of endemism, areas of high to very high anuran species richness, areas with threatened species, and areas with species of a very limited geographical distribution led us to indicate the following 15 priority areas for the conservation of amphibians in the Caatinga biome and semiarid region (Fig. 1): Serra de Maranguape (Q1), Serra de Baturité (Q2), Serra do Araripe (Q12), Serra or Brejo dos Cavalos (Q14), Agreste Alagoano/Pernambucano(Q21), Juazeiro (Q24), Morro do Chapéu (Q30), Chapada Diamantina (Q36, Q39), Jibóia-Timbó (Serra da Jibóia, Q34; Serra do Timbó, Q37), Maracás (Q38), Serras do Sudoeste da Bahia (Q41), Northern Minas Gerais (Q43), Lower Jequitinhonha (Q46), Middle Jequitinhonha (Q47), and Upper Jequitinhonha (Q49). Out of 15 priority areas, 2 did not match any of the four parameters (Juazeiro [Q24] and Agreste Alagoano/Pernambucano [Q21]), but were maintained as priority areas for amphibian conservation of medium importance because of the presence of species with very limited geographical distributions.

All categories of importance presented at least two priority areas (Table 3). As a tiebreaking method, we conducted a complementarity analysis with the use of the cumulative percentage of 103 species found within the 15 priority areas. As seen in Table 3, the highest priority area in the first category of importance was Jibóia-Timbó, because it presented the lowest residual complement (50 species). The overall stratification of categories of importance was maintained by the use of the complementarity principle (Table 4). The changes were the positioning of Maranguape (extremely high importance) and Serra de Baturité (very high importance) among areas of high importance, and Northern Minas Gerais (high importance) among areas of very high importance.

\section{Discussion}

Müller (1973), Kinzey (1982), and Costa et al. (2000) investigated biogeographical patterns of terrestrial vertebrates in the Neotropics (birds, primates, and mammals, respectively) and identified centers and subcenters of faunal dispersal. The Bahia subcenter of faunal dispersal comprises two areas of amphibian endemism identified here as Chapada Diamantina (in part of the SAR and CAA) and 


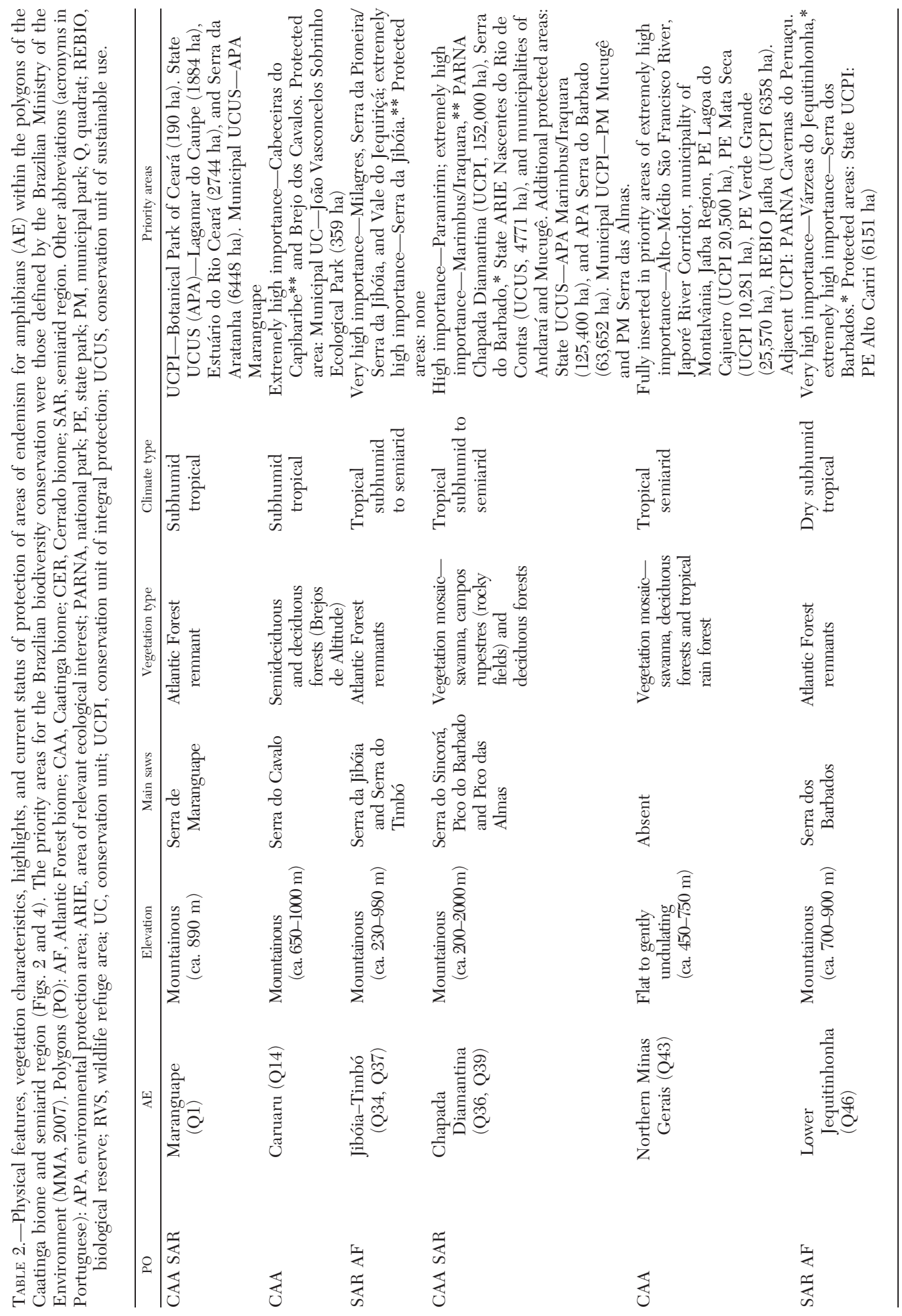




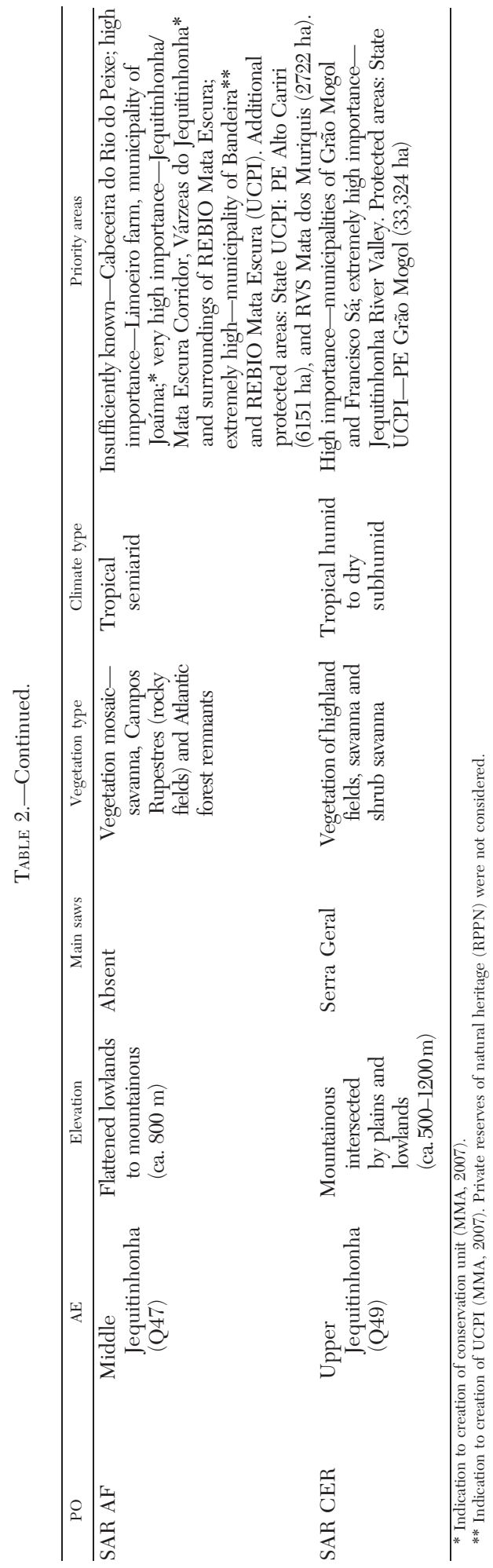

Jibóia-Timbó (SAR; Figs. 2, 4; Q36 + Q39, Q34 +37, respectively); the Pernambuco center of faunal dispersal (Müller, 1973; Costa et al., 2000) comprises the Caruaru area of endemism (in the CAA; Q14 in Fig. 4).

Cracraft (1985) and Goldani et al. (2006) proposed areas of endemism for the South American avifauna and for the Neotropical Platyrrhini (Primates), respectively, the former by the method of species-distribution congruence (Müller, 1973), and the latter by the Parsimony Analysis of Endemicity. Goldani et al. (2006) used different operational geographic units (OGUs: quadrats, river divisions, and areas determined previously by Cracraft, 1985). Cracraft (1985) and Goldani et al. (2006) identified a single large area of endemism encompassing the Caatinga biome and the semiarid region. However, Cracraft (1985) mentioned that, in the future, some of the postulated areas would likely be divided into two or more areas of endemism, which is in agreement with our results (four areas of amphibian endemism for the Caatinga biome and six for the semiarid region). Goldani et al. (2006) showed a strong relationship in the composition of platyrrhine primates among areas of endemism of the Caatinga and Atlantic Forest biomes. These findings coincide with our results because the areas of endemism of amphibians for the Caatinga biome and semiarid region contained $10(66.7 \%)$ and 26 $(76.5 \%)$ species in common with the Atlantic Forest biome, respectively.

In a study of the distribution patterns of amphibians in 12 natural regions of South America, Duellman (1999) found a negative association between species richness and the number of endemic species, which, considering the different scales (continental vs. regional), does not agree with our results. In the Caatinga biome and semiarid region, the number of endemic species and species richness were positively correlated. Positive associations between species richness and the number of endemic species may indicate the existence of centers of speciation (Gonsales, 2008), which in turn make these areas of interest for studying the biogeography of the Caatinga biome and the semiarid region. Furthermore, the combination of high to very high species richness and endemic species in 
TABLE 3.-Priority areas for amphibian conservation at the Caatinga biome and semiarid region. Categories of importance were defined upon four parameters of same weight (0, absence; 1 , presence): $\mathrm{EH}=$ extremely high $(\Sigma=4)$; $\mathrm{VH}$, very high $(\Sigma=3$ or 2$) ; \mathrm{H}=\operatorname{high}(\Sigma=1) ; \mathrm{M}=\operatorname{medium}(\Sigma=0)$. Areas of high and very high species richness: $21-$ 40 species per quadrat (Fig. 3). Threatened species according to IUCN (2001). The priority order within each category of importance was based on cumulative percentage obtained from the complementarity analysis (Table 4), and the residual complement is the difference between the total number of species entered in the analysis $(n=103)$ and the number of species present in an area.

\begin{tabular}{|c|c|c|c|c|c|c|c|c|c|c|}
\hline $\begin{array}{c}\text { Priority } \\
\text { order }\end{array}$ & Priority areas & Quadrats & $\begin{array}{c}\text { Areas of } \\
\text { endemism }\end{array}$ & $\begin{array}{l}\text { Restricted } \\
\text { species }\end{array}$ & $\begin{array}{l}\text { Threatened } \\
\text { species }\end{array}$ & $\begin{array}{l}\text { High or very } \\
\text { high species } \\
\text { richness }\end{array}$ & Sum & $\begin{array}{l}\text { Degree of } \\
\text { importance }\end{array}$ & $\begin{array}{l}\text { Number } \\
\text { of species }\end{array}$ & $\begin{array}{c}\text { Residual } \\
\text { complement }\end{array}$ \\
\hline 1 & Jibóia-Timbó & 34,37 & 1 & 1 & 1 & 1 & 4 & EH & 53 & 50 \\
\hline 2 & Maranguape & 1 & 1 & 1 & 1 & 1 & 4 & EH & 23 & 80 \\
\hline 3 & Chapada Diamantina & 36,39 & 1 & 1 & 0 & 1 & 3 & VH & 34 & 69 \\
\hline 4 & Caruaru & 14 & 1 & 0 & 0 & 1 & 2 & VH & 29 & 74 \\
\hline 5 & Middle Jequitinhonha & 47 & 1 & 0 & 1 & 0 & 2 & VH & 16 & 87 \\
\hline 6 & Maracás & 38 & 0 & 1 & 0 & 1 & 2 & VH & 33 & 70 \\
\hline 7 & Serra de Baturité & 2 & 0 & 1 & 1 & 0 & 2 & $\mathrm{VH}$ & 19 & 84 \\
\hline 8 & Northern Minas Gerais & 43 & 1 & 0 & 0 & 0 & 1 & $\mathrm{H}$ & 20 & 83 \\
\hline 9 & Upper Jequitinhonha & 49 & 1 & 0 & 0 & 0 & 1 & $\mathrm{H}$ & 17 & 86 \\
\hline 10 & Lower Jequitinhonha & 46 & 1 & 0 & 0 & 0 & 1 & $\mathrm{H}$ & 16 & 87 \\
\hline 11 & Serras do Sudoeste baiano & 41 & 0 & 0 & 0 & 1 & 1 & $\mathrm{H}$ & 25 & 78 \\
\hline 12 & Serra do Araripe & 12 & 0 & 0 & 0 & 1 & 1 & $\mathrm{H}$ & 24 & 79 \\
\hline 13 & Morro do Chapéu & 30 & 0 & 0 & 0 & 1 & 1 & $\mathrm{H}$ & 23 & 80 \\
\hline 14 & Juazeiro & 24 & 0 & 0 & 0 & 0 & 0 & M & 14 & 89 \\
\hline 15 & $\begin{array}{l}\text { Agreste Alagoano/ } \\
\text { Pernambucano }\end{array}$ & 21 & 0 & 0 & 0 & 0 & 0 & M & 13 & 90 \\
\hline
\end{tabular}

these areas points to the possible presence of rare or endangered species not yet known to science (Brown and Lomolino, 1998).

Silva et al. (2004) identified four areas of endemism for Passeriformes (Aves) in the Atlantic Forest, three of which include areas of endemism for amphibians identified here (the area of endemism for amphibians and its respective quadrats $[\mathrm{Q}]$ in the CAA or SAR are given in parentheses; Figs. 2 and 4): Costa da Bahia (Jibóia-Timbó, Q34, Q37, SAR), Pernambuco (Caruaru, Q14, CAA), and Bahia Central (Chapada Diamantina, Q36, Q39, CAA, SAR). Silva and Casteleti (2005) contributed more results to those of Silva et al. (2004) by simultaneously considering butterflies, primates, and birds; they identified eight biogeographic subregions in the Atlantic Forest (five areas of endemism and three of transition). These areas of endemism contain six of the areas of amphibian endemism identified here (Figs. 2 and 4): Bahia (Jibóia-Timbó, Q34, Q37, SAR), Brejos Nordestinos (Caruaru, Q14, CAA, SAR; Maranguape, Q1, CAA), and Diamantina (Chapada Diamantina, Q36, Q39, CAA, SAR; Lower Jequitinhonha, Q46, SAR; Middle Jequitinhonha, Q47, SAR). The transition area, São Francisco, contains the Northern Minas Gerais area of endemism (Q43, CAA).
In this study, the areas of endemism identified for amphibians in the Caatinga biome and semiarid region are found in mountainous regions that may exceed 2000 masl, have high humidity, and are covered by isolated forests (Table 2). These mountain massifs include unique ecosystems, such as Campos Rupestres (rocky fields) and seasonal forests. Such environments provide barriers to the dispersal of various phylogenetic groups and are recognized as having high degrees of endemism (Giaretta and Aguiar, 1998; Haddad and Abe, 1999; Naniwadekar and Vasudevan, 2007), favoring the occurrence of geographically restricted amphibian species (Duellman, 1999; Juncá, 2005).

The areas of endemism of amphibians along the Jequitinhonha River Valley are in a transition region (a mosaic of vegetation types: cerrado, campo cerrado, caatinga, high-altitude rocky fields, and Atlantic Forest fragments) between the banks of the São Francisco and Jequitinhonha rivers. Studies on the areas covered by these rivers (Silva and Straube, 1996; Pellegrino et al., 2005) have suggested that they may have acted as barriers to gene flow in lizard and bird populations and could also explain amphibian endemism in the region. Moreover, Feio and Caramaschi 
TABLE 4.-Priority areas for amphibian conservation at the Caatinga biome and semiarid region with the analysis of complementarity of Humphries et al. (1991) used as the unique ordination criterion. Categories of importance are defined in Table 3.

\begin{tabular}{rlcccc}
\hline $\begin{array}{c}\text { Priority } \\
\text { order }\end{array}$ & \multicolumn{1}{c}{ Priority areas } & $\begin{array}{c}\text { Degree of } \\
\text { importance }\end{array}$ & Quadrats & $\begin{array}{c}\text { Number of } \\
\text { complementary species }\end{array}$ & $\begin{array}{c}\text { Accumulative } \\
\text { percentage }\end{array}$ \\
\hline 1 & Jibóia-Timbó & $\mathrm{EH}$ & 34,37 & 53 & 51.5 \\
2 & Chapada Diamantina & VH & 36,39 & 16 & 67.0 \\
3 & Caruaru & $\mathrm{VH}$ & 14 & 7 & 73.8 \\
4 & Northern Minas Gerais & $\mathrm{H}$ & 43 & 6 & 79.6 \\
5 & Middle Jequitinhonha & $\mathrm{VH}$ & 47 & 6 & 85.4 \\
6 & Maracás & $\mathrm{VH}$ & 38 & 3 & 88.3 \\
7 & Upper Jequitinhonha & $\mathrm{H}$ & 49 & 3 & 91.3 \\
8 & Maranguape & $\mathrm{EH}$ & 1 & 2 & 93.2 \\
9 & Lower Jequitinhonha & $\mathrm{H}$ & 46 & 2 & 95.1 \\
10 & Serras do Sudoeste baiano & $\mathrm{H}$ & 41 & 1 & 96.1 \\
11 & Serra do Araripe & $\mathrm{H}$ & 12 & 1 & 97.1 \\
12 & Serra de Baturité & $\mathrm{VH}$ & $\mathrm{2}$ & 1 & 98.1 \\
13 & Juazeiro & $\mathrm{M}$ & 24 & 1 & 99.0 \\
14 & Agreste Alagoano/Pernambucano & $\mathrm{M}$ & 21 & 1 & 100 \\
15 & Morro do Chapéu & $\mathrm{H}$ & 30 & 0 & 100 \\
\hline
\end{tabular}

(2002) pointed to the Jequitinhonha River as a possible disperser of amphibians and reptiles from the coast to the interior of Brazil. In fact, the species that are unique to the area of endemism in the Jequitinhonha River Valley (Fig. 2; Q47) are typical of the coastal Atlantic Forest.

The priority areas for biodiversity conservation proposed by the MMA (2007) coincided fully with the areas of endemism detected by the method used here, which is important for amphibian conservation in the Caatinga biome and semiarid region. However, there are some aspects that deserve attention because the degree of importance received by each area was not equal.

A more worrying aspect is the presence of anuran species restricted to areas not protected by CUIPs, such as the Serra da Jibóia (Q34), Serra do Timbó (Q37), and Serra de Baturité (Q2). This fact indicates that there is insufficient knowledge about species distributions in these regions or that the methods previously used to select priority areas for their conservation may have been ineffective. The failure to include these areas of endemism is serious, as species with restricted distributions are more susceptible to extinction (Brown and Lomolino, 1998). We emphasize here the importance of the immediate creation of at least three conservation units of integral protection: two CUIPs in the $\mathrm{AE}$ Jibóia-Timbó, one in the Serra da Jibóia and another in the Serra do Timbó, the latter comprising the Mata de Santa Rita remnant (extremely high importance), and at least one CUIP in the Serra do Baturité (very high importance). In addition, we also encourage the creation of Private Reserves of Natural Heritage (Reserva Particular do Patrimônio Natural-RPPN) in these three priority areas.

The municipality of Maracás in the State of Bahia deserves special attention because it only has one conservation unit of integral protection (Maracás Biological Reserve), and it is very small (ca. $10 \mathrm{ha}$ ). This municipality is the type locality for 11 species of frogs: $D$. novaisi, D. oliveirai, Phyllodytes tuberculosus, Phyllomedusa nordestina, Physalaemus cicada, Rhinella jimi, Scinax camposseabrai, Scinax eurydice, S. bromelicola, Trachycephalus atlas, and X. eugenioi. The creation of more conservation units of integral protection in Maracás and expansion of the area currently occupied by the Maracás Biological Reserve are necessary and warrant further study.

The Caatinga biome and the Brazilian semiarid region are partially different with respect to the priority areas for amphibian conservation. The geographical boundaries of these regions are not coincident, mainly in their southern limits, where the boundaries of the semiarid region include transitional areas between the Atlantic Forest biome and the Caatinga biome. These transitional areas 
differ from the Caatinga biome in species composition and are possibly more influenced by the Atlantic Forest biome. This hypothesis is supported by the presence of four exclusive areas of endemism composed of five unique OGUs in the southern and southeastern limits of the semiarid region: Jibóia-Timbó (Q34Q37), Lower Jequitinhonha (Q46), Middle Jequitinhonha (Q47), and Upper Jequitinhonha (Q49). Moreover, when transitional areas in the southern limits of the semiarid region are considered, two areas of endemism identified for the Caatinga biome (Caruaru [Q14] and Northern Minas Gerais [Q43]) are no longer recognized, because five of their seven exclusive species also occur in OGUs unique to the semiarid region (Q32, Q34, Q37, Q38, Q46, and Q48).

These conflicting results have implications for the conservation efforts for the Caatinga biome and the Brazilian semiarid region. Conservation initiatives for these areas reflect distinct research and conservation policies adopted by the Brazilian government. For example, the Caatinga Thematic Group at the Brazilian Ministry of Environment (MMA) focuses on identifying priority areas for the Caatinga biome. In contrast, the Biodiversity Research Program, which is part of the Brazilian Ministry of Science, Technology, and Innovation (MCTI), conducts research and searches for high-biodiversity areas in the whole semiarid region. Our results show that assessing priority areas within each region alone is not adequate. Rather, combining results into a single proposal of priority areas is paramount to safeguard the biodiversity of both the semiarid region and Caatinga biome in Brazil.

Finally, it is imperative to make greater investments in faunal inventories, studies of community and population ecology, and longterm monitoring of the Caatinga biome and semiarid region to understand the distribution patterns and areas of amphibian endemism within these regions better. There are large geographical gaps in the sampling of amphibians. The presence of patches of relictual forest, rocky fields, high-altitude fields, and mountain massifs that have not yet been fully surveyed, suggest that there are more geographically restricted amphibian species and, consequently, areas of endemism than those found in this study.

Acknowledgments.-We thank Ulisses Caramaschi, José P. Pombal, Jr., Hussam Zaher, Flora A. Juncá, and Ricardo Rosa for providing space and facilities during the development of this article and allowing us to examine specimens under their care; Flora A. Juncá and Eliza Maria X. Freire for critically reading and improving the Portuguese version of the manuscript, and Camila A. Souto and Adrian A. Garda for the English version; Angela Zanata and Priscila Camelier for helpful comments during the development of the research; Ivan Sérgio Nunes, Gindomar G. Santana, Washington L. S. Vieira, Carolina C. Mello, and Tasso M. Lima for assistance during works in the herpetological collections; and the Conselho Nacional de Desenvolvimento Científico e Tecnológico (CNPq, process 302542/2008-6) for a fellowship to Marcelo F. Napoli.

\section{Literature Cited}

Ab’Sáber, A.N. 1977. Os domínios morfoclimáticos na América do Sul. Primeira aproximação. Geomorfologia 52:1-21.

Angulo, A. 2008. Frostius erythrophthalmus. In IUCN (2009). IUCN red list of threatened species. Version 2009.1. Available at http://www.iucnredlist.org. Cited 10 November 2009.

Brown, J.H., and M.V. Lomolino. 1998. Biogeography, 2nd ed. Sinauer Associates, Inc., Massachusetts, USA.

Carnaval, A.C. 2002. Phylogeography of four frog species in forest fragments of northeastern Brazil: a preliminary study. Integrative and Comparative Biology 42: 913-921.

Carnaval, A.C., and C. Moritz. 2008. Historical climate modelling predicts patterns of current biodiversity in the Brazilian Atlantic forest. Journal of Biogeography 35:1187-1201.

CHESF (Companhia Hidroelétrica do São Francisco). 2001. Aptidão Bioclimática no Bioma Caatinga, PROBIO 2001. Available at http://mapas.mma.gov.br/i3geo/ datadownload.htm.

Costa, L.P., Y.L. Leite, G.A.B. Fonseca, and M.T. Fonseca. 2000. Biogeography of South American forest mammals: Endemism and diversity in the Atlantic Forest. Biotropica 32:872-881.

Cracraft, J. 1985. Historical biogeography and patterns of differentiation within the South America avifauna. Areas of endemism. Ornithological Monographs 36:49-84.

Cruz, C.A.G., M.F. Napoli, and P.M. Fonseca. 2008. A new species of Phasmahyla Cruz, 1990 (Anura: Hylidae) from the State of Bahia, Brazil. South American Journal of Herpetology 3:187-195.

Duellman, W.E. 1999. Distribution patterns of amphibians in South America. Pp. 255-328 in W.E. Duellman (Ed.), Patterns of Distribution of Amphibians: A Global Perspective. The Johns Hopkins University Press, Maryland, USA.

Duellman, W.E., and L. Trueb. 1986. Biology of amphibians. McGraw-Hill, New York, USA.

ESRI (Environmental Systems Research Institute). 1997. DCW: Digital Chart of the World. Available at http:// www.maproom.psu.edu/dcw. 
ESRI (Environmental System Research Institute). 2000. ArcView GIS Version 3.2a. New York, USA.

Feio, R.N., and U. Caramaschi. 2002. Contribuição ao conhecimento da herpetofauna do nordeste do estado de Minas Gerais, Brasil. Phyllomedusa 1:105-111.

Frost, D.R. 2009. Amphibian species of the world: An online reference. Version 5.3 (12 February, 2009). Available at http://research.amnh.org/herpetology/amphibia. American Museum of Natural History, New York, USA.

GEOMINAS (Geoprocessamento em Minas Gerais). 2009. Atlas de zoneamento agroclimático do Estado de Minas Gerais_SEA (1980). Available at http://www. geominas.mg.gov.br.

Giaretta, A.A., and O. Aguiar, Jr. 1998. A new species of Megaelosia from the Mantiqueira Range, Southeastern Brazil. Journal of Herpetology 32:80-83.

Goldani, A., G.S. Carvalho, and J.C. Bicca-Marques. 2006. Distribution patterns of Neotropical primates (Platyrrhini) based on parsimony analysis of endemicity. Brazilian Journal of Biology 66:61-74.

Goloboff, P., J. Farris, and K. Nixon. 2008. TNT: A free program for phylogenetic analysis. Cladistics 24: $774-786$.

Gonsales, E.M.L. 2008. Diversidade e Conservação de Anfíbios Anuros no Estado de Santa Catarina, sul do Brasil. Ph.D. Dissertation, Instituto de Biociências da Universidade de São Paulo, Brazil.

Haddad, C.F.B., and A. Abe. 1999. Répteis e anfíbios. Pp. 19-21. In Workshop Floresta Atlântica e Campos Sulinos. Available at http://www.conservation.org.br/ publicacoes/files/Sumario.pdf.

Humphries, C.J., R.I. Vane-Wright, and P.H. Williams. 1991. Biodiversity reserves: Setting new priorities for the conservation of wildlife. Park 2:34-38.

IBGE (Instituto Brasileiro de Geografia e Estatística). 2004a. Biomas do Brasil (1:5.000.000). IBGE-Departamento de Cartografia (DECAR), Rio de Janeiro, Brazil. Available at http://mapas.mma.gov.br/i3geo/datadownload. htm.

IBGE (Instituto Brasileiro de Geografia e estatística). 2004b. Mapa de biomas do Brasil: Primeira aproximação. Ministério do Meio Ambiente e IBGE, Diretoria de Geociências, Coordenação de Recursos Naturais e Estudos Ambientais, Brazil.

IUCN (International Union for Conservation of Nature). 2001. The IUCN red list of threatened species. Available at http://www.iucnredlist.org/.

Juncá, F.A. 2005. Anfíbios e répteis. Pp. 337-356 in F.A. Juncá, L. Funch, and W. Rocha (Eds.), Biodiversidade e Conservação da Chapada Diamantina. Ministério do Meio Ambiente, Distrito Federal, Brazil.

Kinzey, W.G. 1982. Distribution of primates and forest refuges. Pp. 456-482 in G.T. Prance (Ed.), Biological Diversification in the Tropics. Columbia University Press, New York, USA.

Maddison, W.P., and D.R. Maddison. 2009. Mesquite: A modular system for evolutionary analysis. Version 2.71 . Available at http://mesquiteproject.org.

MIN (Ministério da Integração Nacional). 2005. Nova delimitação do Semi-Árido brasileiro. Available at http:// www.mi.gov.br/desenvolvimentoregional/publicacoes/ delimitacao.asp. Secretaria de Política e Desenvolvimento Regional, Distrito Federal, Brazil.
MMA (Ministério do Meio Ambiente). 2007. Áreas prioritárias para conservação, uso sustentável e repartição de benefícios da biodiversidade brasileira. AtualizaçãoPortaria MMA No. 9, de 23 de janeiro de 2007. Ministério do Meio Ambiente, Secretaria de Biodiversidade e Florestas, série biodiversidade, Distrito Federal, Brazil.

Mondragón, E.A., and J.J. Morrone. 2004. Propuesta de áreas para la conservación de aves de México, empleando herramientas panbiogeográficas e índices de complementariedad. Interciencia 29:112-120.

Morrone, J.J. 1994. On the identification of areas of endemism. Systematic Biology 43:438-441.

Morrone, J.J. 2006. Biogeographic areas and transition zones of Latin America and Caribbean islands based on panbiogeographic and cladistic analyses of the entomofauna. Annual Review of Entomology 51:467-494.

Morrone, J.J., and T. Escalante. 2002. Parsimony analysis of endemicity (PAE) of Mexican terrestrial mammals at different area units: When size matters. Journal of Biogeography 29:1095-1104.

Müller, P. 1973. The dispersal centers of terrestrial vertebrates in the Neotropical realm. A study in the evolution of the Neotropical Biota and its native landscape. Biogeographica 2:1-250.

Naniwadekar, R., and K. Vasudevan. 2007. Patterns in diversity of anurans along an elevational gradient in the Western Ghats, south India. Journal of Biogeography 34:843-852.

Peixoto, O.L., and B.V.S. Pimenta. 2004. Dendropsophus novaisi. In IUCN (International Union for Conservation of Nature), IUCN red list of threatened species, Version 2009.1. Available at http://www.iucnredlist.org.

Pellegrino, K.C.M., M.T. Rodrigues, A. Waite, M. Morando, Y. Yonenagayassuda, and J.W. Sites, Jr. 2005. Phylogeography and species limits in the Gymnodactylus darwinii complex (Gekkonidae, Squamata): Genetic structure coincides with river systems in the Brazilian Atlantic Forest. Biological Journal of Linnean Society 85:13-26.

Platnick, N.I. 1991. On areas of endemism. Australian Systematic Botany 4:1-11.

Rizzini, C.T. 1979. Tratado de Fitogeografia do Brasil. HUCITEC/EDUSP, Brazil.

Rosen, B.R. 1988. From fossils to earth history: Applied historical biogeography. Pp. 437-481 in A.A. Myers and P. Giller (Eds.), Analytical Biogeography: An Integrated Approach to the Study of Animal and Plant Distributions. Chapman and Hall, UK.

Santos, A.M.M., and M. Tabarelli. 2003. Variáveis múltiplas e desenho de unidade de conservação: uma prática urgente para a Caatinga. Pp. 735-776 in I.R. Leal, M. Tabarelli, and J.M.C. Silva (Eds.), Ecologia e conservação da Caatinga. Universidade Federal de Pernambuco, Brazil.

Silva, J.M.C., and C.H.M. Casteleti. 2005. Estado da biodiversidade da Mata Atlântica brasileira. Pp. 43-59 in C. Galindo-Leal and I.G. Câmara (Eds.), Mata Atlântica: Biodiversidade, Ameaças e Perspectivas. Fundação SOS Mata Atlântica e Conservação Internacional, Brazil.

Silva, J.M.C., and F.C. Straube. 1996. Systematics and biogeography of scaled woodcreepers (Aves: Dendrocolaptidae). Studies Neotropical Fauna and Environment 31:3-10. 
Silva, J.M.C., M.C. Sousa, and C.H.M. Castelletti. 2004. Areas of endemism for passerine birds in the Atlantic Forest, South America. Global Ecology and Biogeography 13:85-92

Silva, M.B. 2008. Biogeografia de Opiliões Gonyleptidae na Mata Atlântica, com Revisão Sistemática de Hernandariinae (Arachnida, Opiliones). Ph.D. Dissertation, Instituto de Biociências da Universidade de São Paulo, Brazil.

Silvano, D., and D.M. Borges-Nojosa. 2004. Adelophryne baturitensis. In IUCN (International Union for Conservation of Nature). IUCN red list of threatened species. Version 2009.1. Available at http://www.iucnredlist.org.

Silvano, D., and O.L. Peixoto. 2004a. Sphaenorhynchus bromelicola. In IUCN (International Union for Conservation of Nature), IUCN red list of threatened species. Version 2009.1. Available at http://www.iucnredlist. org.

Silvano, D., and O.L. Peixoto. 2004b. Dendropsophus dutrai. In IUCN (International Union for Conservation of Nature), IUCN red list of threatened species. Version 2009.1. Available at http://www.iucnredlist. org.

Skuk, G., and F.A. Juncá. 2004. Ceratophrys joazeirensis. In IUCN (International Union for Conservation of Nature), IUCN red list of threatened species. Version 2009.1. Available at http://www.iucnredlist.org.

SNUC (Sistema Nacional de Unidades de Conservação da Natureza). 2000. Lei 9.985, de 18 de julho de 2000. Available at http://www.mma.gov.br. Ministério do Meio Ambiente/Secretaria de Biodiversidade e Florestas, Distrito Federal, Brazil.

Sokal, R.R., and F.J. Rohlf. 1981. Biometry: The Principles and Practice of Statistics in Biological Research. W.H. Freeman and Company, New York, USA.

SPDR (Secretaria de Políticas de Desenvolvimento Regional). 2005. Redelimitação do Semi-Árido Nordestino. Available at http://mapas.mma.gov.br/i3geo/ datadownload.htm

Tabarelli, M., and J.M.C. Silva. 2004. Áreas e ações prioritárias para a conservação da biodiversidade da Caatinga. Pp. 777-796 in I.R. Leal, M. Tabarelli, and J.M.C. Silva (Eds.), Ecologia e Conservação da Caatinga. Universidade Federal de Pernambuco, Brazil.

USGS (US Geological Survey). 1996. GTOPO30: Global 30 arc second elevation data set. Available at http:// wwwl.gsi.go.jp/geowww/globalmap-gsi/gtopo30/gtopo30. html.

Velloso, A.L., E.V.S.B. Sampaio, and F.G.C. Pareyn. 2002. Ecorregiões-Proposta Para o Bioma Caatinga. Associação Plantas do Nordeste/Instituto de Conservação Ambiental, The Nature Conservancy do Brasil, Brazil.

Verdade, V. 2008. Allobates olfersioides. In IUCN (International Union for Conservation of Nature), IUCN Red List of Threatened Species. Version 2009.2. Available at http://www.iucnredlist.org

Accepted: 3 November 2011

Associate Editor: Christopher Raxworthy
APPENDIX I.

List of species included in the analysis.

Aromobatidae
Allobates olfersioides

Brachycephalidae

Ischnocnema bilineata

Ischnocnema vinhai

Bufonidae

Frostius erythrophthalmus

Frostius pernambucensis

Rhinella boulengeri

Rhinella crucifer

Rhinella granulosa

Rhinella hoogmoedi

Rhinella jimi

Rhinella rubescens

Ceratophryidae

Ceratophrys aurita

Ceratophrys joazeirensis

Craugastoridae

Haddadus binotatus

Cycloramphidae

Odontophrynus carvalhoi

Proceratophrys cristiceps

Proceratophrys renalis

Proceratophrys schirchi

Rupirana cardosoi

Thoropa miliaris

Eleutherodactylidae

Adelophryne baturitensis

Adelophryne maranguapensis

Adelophryne pachydactyla

Hemiphractidae

Gastrotheca fissipes

Gastrotheca flamma

Hylidae

Agalychnis granulosa

Aplastodiscus cavicola

Aplastodiscus ibirapitanga

Aplastodiscus sibilatus

Aplastodiscus weygoldti

Bokermannohyla capra

Bokermannohyla diamantina

Bokermannohyla itapoty

Bokermannohyla juiju

Bokermannohyla oxente

Bokermannohyla saxicola

Corythomantis greeningi

Dendropsophus branneri

Dendropsophus dutrai

Dendropsophus elegans

Dendropsophus minutus

Dendropsophus nanus

Dendropsophus novaisi

Dendropsophus oliveirai

Dendropsophus soaresi

Hypsiboas albomarginatus 
Appendix I.

Continued.

Hypsiboas albopunctatus

Hypsiboas crepitans

Hypsiboas exastis

Hypsiboas faber

Hypsiboas lundii

Hypsiboas polytaenius

Hypsiboas pombali

Hypsiboas raniceps

Phasmahyla timbo

Phyllodytes luteolus

Phyllodytes melanomystax

Phyllodytes tuberculosus

Phyllodytes wuchereri

Phyllomedusa bahiana

Phyllomedusa nordestina

Pseudis bolbodactyla

Pseudis fusca

Scinax argyreornatus

Scinax auratus

Scinax camposseabrai

Scinax eurydice

Scinax fuscomarginatus

Scinax fuscovarius

Scinax nebulosus

Scinax pachycrus

Scinax strigilatus

Sphaenorhynchus bromelicola

Sphaenorhynchus prasinus

Trachycephalus atlas

Trachycephalus mesophaeus

Trachycephalus typhonius

Vitreorana eurygnatha

Xenohyla eugenioi

Hylodidae

Crossodactylus cyclospinus
Appendix I.

Continued.

Leiuperidae

Physalaemus albifrons

Physalaemus centralis

Physalaemus cicada

Physalaemus cuvieri

Physalaemus kroyeri

Pleurodema diplolister

Pseudopaludicola mystacalis

Leptodactylidae

Leptodactylus caatingae

Leptodactylus furnarius

Leptodactylus fuscus

Leptodactylus hylaedactylus

Leptodactylus mystaceus

Leptodactylus mystacinus

Leptodactylus natalensis

Leptodactylus latrans

Leptodactylus podicipinus

Leptodactylus pustulatus

Leptodactylus syphax

Leptodactylus troglodytes

Leptodactylus vastus

Microhylidae

Chiasmocleis albopunctata

Dermatonotus muelleri

Elachistocleis ovalis

Elachistocleis piauiensis

Pipidae

Pipa carvalhoi

Ranidae

Lithobates palmipes

Strabomantidae

Strabomantis aramunha 